\title{
ON THE HISTORY OF THE GENITIVE PLURAL IN SLAVIC, BALTIC, GERMANIC, AND INDO-EUROPEAN
}

\author{
Frederik KORTLANDT \\ University of Leiden
}

Received November 1977

Cecylii

1.

A correct interpretation of the genitive plural forms in Slavic and related languages requires a detailed chronological analysis of the material. At every stage of development we have to reckon with both phonetically regular and analogical forms. Analogy operates quite often along the same lines in different periods. Explaining an analogic change amounts to indicating a model, a motivation, and a stage of development for its effectuation. If one of these cannot be indicated, we must look for a phonetic explanation.

\section{2.}

The Slavic gen. pl. ending - $\checkmark$ points to IE *-om. It has been suggested that the ending arose from the strong reduction of an earlier *-om and that the origin of the quantitative alternations in the stem-final syllable which are found in the daughter languages must be sought in this development (e.g., Van Wijk 1923: 97; Stang 1957: 98). The argument cannot be maintained for chronological reasons. If the reduction was anterior to the rise of the new timbre distinctions $(a-o$, etc.), the quantitative alternations in the stem would be reflected as timbre alternations in the contemporary languages. If the reduction was posterior to the rise of the new timbre distinctions, the timbre of the desinential vowel remains unexplained. I conclude that the ending continues IE *-om. 
3.

The quantitative alternations in the gen. pl. forms of the modern languages date from different periods. Their chronological analysis requires the following information about the history of Slavic accentuation. ${ }^{1 *}$

(1) The rise of the new timbre distinctions entailed the neutralization of quantitative oppositions in pretonic syllables. In stressed syllables, acute vowels became neutral with respect to quantity.

(2) Distinctive quantity in pretonic syllables was restored as a result of Dybo's law, according to which any stressed vowel which was neither acute nor circumflex lost the stress to the following syllable, if there was one. Originally pretonic vowels became distinctively short and long vowels which lost the stress in accordance with Dybo's law remained distinctively long. This interpretation of the facts accounts for the quantitative difference between SCr. màlina and páliti, between Po. ręka and trąba.

(3) At a later stage, acute vowels in stressed syllables became distinctively short and merged with short rising vowels of different origin. This class of vowels were lengthened dialectally under various conditions after the disintegration of Common Slavic.

(4) According to Stang's law, the stress was retracted from long falling vowels which had received the stress as a result of Dybo's law. This retraction, which was one of the last Common Slavic innovations, yielded the characteristic accentual mobility of such paradigms as $\mathrm{Ru}$. nošú, nósiš'.

\section{4.}

In Slovene, we find a quantitative difference between the nom. sg. kònj and the gen. pl. kónj. Since these forms were homophonous at a certain stage, one of them must have borrowed its quantity from another paradigm. The nom. sg. form cannot be analogical because there is no model for it: this is the only type with a short root vowel. On the other hand, there are gen. pl. forms where length can hardly be analogical, e.g. gór < * gorì, Po. $r a k<{ }^{*}$ rqki. I conclude that the new long vowel arose phonetically as a consequence of the retraction of the stress from a final jer. Since the nom. sg. konj shows a short root vowel, we have to assume that the paradigm of this word did not yet have final stress at the time when the retraction operated. Thus, we can date the retraction of the stress from final jers

* For text of footnotes see pp. 296-298. 
to the period between the rise of the new timbre distinctions and Dybo's law. When the paradigm of the word konj received final stress as a result of Dybo's law, final jers had already lost their stressability and the accent did not shift in the nom. sg. and gen. pl. forms of this word.

5.

After the retraction of the stress from final jers and the rise of length in the gen. pl. of mobile paradigms, the new quantity was introduced analogically in originally stem-stressed gen. pl. forms. Several layers of analogic development can be distinguished. The West Slavic, Ukrainian, and Cakavian material shows that the generalization of length in monosyllabic stems, i.e. in such cases as Sln. kónj, was anterior to the merger of stressed acute vowels with short rising vowels of different origin. Since the acute vowels were still neutral with respect to quantity at this stage, they could not be affected by the analogical spread of length in the gen. $\mathrm{pl}^{2}$ Thus, the phonetically regular short root vowel has been preserved to the present day in Po. pęt, blot, Cz. krav, dèl, cf. Slovincian làt. ${ }^{3}$

6.

After the loss of distinctive pitch, the breakdown of the accentual paradigms, and the phonetic lengthening before final voiced consonants in Lekhitic, the original quantitative relationships were derailed in a number of instances, e.g. OPo. lyaath, ottychmyaasth, Po. dial. låt, dotyxčås, Slc. rąk instead of * róuk. ${ }^{4}$ In the consonant stems, Slovene continues the original distribution of the Proto-Slavic accentual paradigms most faithfully. Here sẹme and jágnje reflect fixed stress on the initial syllable, pléme and téle fixed stress on the second syllable, and imế and prasế accentual mobility, cf. SCr. jägnje, tèle, prâse. The expected quantity in the stem-final syllable before the zero ending of the gen. pl. is long in the accentually mobile type and short in the types with fixed stress. In Slovincian, remjóun (gen. pl. of rèmja) has taken the length of mjóun (gen. pl. of imja), whereas Po. imion shows the converse analogical development. On the other hand, Slc. jàgnjąt and cielat have preserved the phonetically regular short vowel, while the corresponding Polish forms show analogical length. The long vowel has been preserved in Slc. votroč́ut (gen. pl. of 
vùotroča, the only polysyllabic word of this flexion class which dates back to the Proto-Slavic period).

7.

In early Czech, a short rising vowel in an open first syllable of dissyllabic words was lengthened unless the following syllable contained a long vowel (cf. Kortlandt 1975: 19), e.g. kámen, kráva, kůže, můžeš, psáti vs. řezati, baviš, nosišs, gen. sg. kamene, gen. pl. krav, inst. pl. kravami, kožemi. The same development can be established for Upper Sorabian. As a result of this phonetic change, the old alternation between a long vowel in the gen. pl. and a short vowel in the other case forms, which was subsequently eliminated from the literary language except for the archaic remnant dokoŕan, became coupled with the converse alternation in stem-stressed dissyllabic words. Besides, there was a type with an original long vowel which was preserved throughout the paradigm, e.g. brázda, gen. pl. brázd, and a polysyllabic type with an invariably short vowel in the stem-final syllable. The quantitative alternations have largely been eliminated in the modern language, e.g. čas, dým, gen. sg. času, dýmu. In Central Slovak, length was generalized in the gen. pl. form, as it was in South Slavic. ${ }^{5}$

8.

Ru. ogoród, pozolóta show that the East Slavic pleophony was posterior to Dybo's law. On the other hand, the pleophony was anterior to the merger of stressed acute vowels with short rising vowels of different origin because the distinction between (short) acute and (long) neo-acute was preserved in Ukr. moróz < ${ }^{*}$-orò- vs. holiv < ${ }^{*}$-oló-. ${ }^{6}$ The phonetically regular short vocalism in the gen. pl. of stems with an acute root vowel was preserved in such cases as kolód, but eliminated in beriz, koriv, etc. on the analogy of borid, holiv after the loss of distinctive pitch. ${ }^{7}$

9.

In South Slavic, a second wave of analogical lengthening in the gen. pl. can be dated to the period between the merger of stressed acute vowels with short rising vowels of different origin and Stang's law. At this stage, there 
was no pitch opposition on short vowels in non-initial syllables. Analogical lengthening of a stressed short vowel in the stem-final syllable of a polysyllabic word yielded a long falling vowel, which subsequently lost the stress to the preceding syllable in accordance with Stang's law, e.g. SCr. lôpātā, köljēnā, Čak. (Korčula) kôlīn (Moskovljević 1950: 197), Bulg. gódin, stótin (Kodov 1929: 72). This development did not reach the Slovenian and North Čakavian dialectal area before Stang's law except for nouns with a jer in the stem-final syllable (cf. Steinhauer 1973: 218ff). ${ }^{8}$ The relative chronology is based on the SCr. gen. pl. jêzik $\bar{a}$. The short vowel in the first syllable of Po. jezyk and SCr. jèzik shows that this word had fixed stress on its second syllable before Dybo's law already. It follows that length could not be introduced analogically in its gen. pl. form before the merger of stressed acute vowels with short rising vowels of different origin because the acute vowels were still neutral with respect to quantity at that time. If the generalization of length had been posterior to Stang's law, the stress would not have been retracted in the gen. pl. of this word. In the gen. pl. prözōra of the word pròzor, which received fixed stress on its second syllable as a result of Dybo's law, the rise of length can be dated to the same period as in jëzika

10.

The generalization of length in the gen. p1. after the merger of stressed acute vowels with short rising vowels of different origin gave rise to the apparent neo-circumflex in Sln. $k r a ̂ v$, lipp, and in the corresponding Čakavian forms. After Stang's law, the generalization of length affected the remaining polysyllabic words in all South Slavic dialects which preserve distinctive quantity, e.g. Čak. (Novi) susêd, telêt, besêd, kolên. The rise of length cannot have been anterior to Stang's law in these forms because the stress was not retracted. On the other hand, it was anterior to the phonetic lengthening of short vowels before tautosyllabic resonants in Cakavian because of the tonal difference between the gen. pl. progon and the nom. sg. prōgón (cf. Belić 1909: 213). Since the latter form shows the normal reflex of a short vowel before the word-final resonant, the former must have received its length at an earlier stage, viz. between Stang's law and the C̆akavian lengthening. The long rising vowel in gen. pl. forms such as žén is still older: it belongs to the first, Common Slavic wave of analogical lengthening in this morphological category. 
11.

The origin of the SCr. gen. pl. ending $-\bar{a}$ belongs to the most debated problems in Slavic historical morphology. ${ }^{9}$ The old view that the $-\bar{a}$ continues Proto-Slavic $-\boldsymbol{z}$, which was first put forward a hundred years ago by Baudouin de Courtenay and which is still encountered occasionally in the recent literature, cannot be maintained for chronological reasons. Final -b was lost in the Serbo-Slovenian dialectal area as early as the tenth century, while the gen. pl. ending $-\bar{a}$ appeared in Serbo-Croat in the 14th and in Slovene in the 17 th century. Moreover, the rise of the medial syllable in SCr. sestárā, otác $\bar{a}$ would remain unexplained if $-\bar{a}$ continued the ProtoSlavic ending $-z$. The correct solution was indicated by Oblak (1890: 439f), who pointed to the oblique plural endings -am, -ah, -ami as the source of an analogical development in the gen. pl. form. ${ }^{10}$ As Karlgren pointed out (1911: 9), this suggestion does not explain the length of the gen. pl. ending. As a model for the analogical development, Karlgren assumed the existence of a paradigm with a gen. pl. ending $-i$ and a loc. pl. ending -ih (1911: 15). I think that this is correct. The only problem is the origin of the latter paradigm. According to Karlgren (1911: 16), it came into being when the gen. pl. ending of the $i$-stems $-i$ was introduced in the paradigm of the jo-stems, which had inherited the loc. pl. ending -ih. However, the normal gen. pl. and loc. pl. endings of the jo-stems in Old Serbo-Croat were zero and -ěh, respectively, while the loc. pl. ending of the $i$-stems was $-e h$. The latter ending must be due precisely to the influence of the jo-stems, cf. Sln. dat. pl. možêm, kostệm (with the accentuation of the $i$-stems) vs. loc. pl. možẹ́h, kostẹ́h (with the accentuation of the $o$-stems). Besides, there is a fatal objection which I am surprised not to find in the ample literature on the subject. The loc. pl. ending of the jo-stems -ih contained a long vowel while the ending -ah was short, so that Karlgren's analogy does not account for the length in the new gen. pl. ending. As far as I see, the matter has finally been settled by Johnson (1972: 349ff), who pointed out that the dat. pl. and loc. pl. endings $-i m,-i h$ which are required in the model paradigm were the result of an analogical development themselves. ${ }^{11}$

\section{2.}

The relative chronology of the Slavic sound changes forces us to date the narrowing of IE ${ }^{*}$-om to ${ }^{*}-u N$ to the Balto-Slavic period. First, it was 
anterior to the barytonesis of the IE oxytone neuters, which was a result of the late Balto-Slavic retraction of the stress from final open syllables (cf. Kortlandt 1975: 45). Second, it was anterior to the loss of final $* t / d$ because the $3 \mathrm{rd}$ pl. ending of the Slavic thematic aorist $-q<*_{\text {-ont }}$ remained distinct from the 1 st sg. ending $-\mathbf{b}<*^{*}$-om. The latter change was in turn anterior to the late Balto-Slavic retraction because the stress was retracted from the gen. sg. ending $*_{-} \bar{o}(d)$, e.g. Lith. dievo, and from the $3 \mathrm{rd}$ sg. ending of the thematic aorist*-e(t), e.g. SCr. plète (cf. Kortlandt 1975: 6). The loss of final $* t / d$ was also anterior to Winter's law, which belongs to the last Balto-Slavic developments, because of the Slavic neuter pronoun to (not **ta) from IE *tod (cf. Winter 1976: Kortlandt 1977).

\section{3.}

The suggestion that IE *-om yields $-q$ in Lithuanian is based exclusively on the acc. sg. ending of the $o$-stems, e.g. diẽvq. However, this $-q$ can easily be explained as an analogical development on the basis of the $i$ - and $u$ stems, e.g. avis, sūnùs, acc. sg. ãvĭ, sünu. On the other hand, the suggestion that the gen. pl. ending $-u$ continues IE ${ }_{-}^{*} \bar{o} m$ is neither supported by comparable sound changes nor corroborated by other instances than this very ending. Indeed, the nom. sg. of the $n$-stems akmuo shows that word-final *-on developed into $-u o$, cf. Gr. $\ddot{\alpha}_{\kappa} \mu \omega \nu$. Slavic kamy proves that the final nasal was preserved in Balto-Slavic because $*_{-}-\bar{o}$ is reflected as $-a$ in other instances. There is no reason to speculate about IE sandhi forms, for which there is absolutely no evidence in Balto-Slavic. I conclude that Lith. $-u$ is the phonetic reflex of $\mathrm{IE}^{*}$-om.

\section{4.}

The evaluation of the Old Prussian evidence requires a new philological analysis of the material. Plenty of useful information remains hidden in the texts because investigators have been reluctant to rely on the orthography. ${ }^{12}$ The first step towards a better understanding of this interesting language is a separate examination of the Enchiridion, the spelling of which is much more consistent than is generally assumed. The other texts must be reconsidered in the light of that inquiry. In this paper I shall limit myself to the language of the Enchiridion. ${ }^{13}$ 
15.

The gen. pl. ending is -an in nouns and -on in pronouns. In nouns, the ending is never written -on. The ending of steisan (75.7), steisan (71.32) is induced by the immediately following grijkan, grikan and must be corrected to -on, which occurs $20 \times$. The same must be assumed for the form steisan (73.7), which seems to agree with warrin. The ending of tenneison $(11 \times)$, tenneison $(5 \times)$ is never written -an. The ending of Noüsan (79.31), ioüsan (67.2) must be corrected to -on, which occurs $52 \times$. The form iousan (57.5) agrees with the following Dusin and is no gen. pl. form, cf. ioüsons mukinnewins (57.4). I agree with Trautmann (1910: 220) that the nominal ending -an contains an analogical vowel which was taken from the other case forms. Can the pronominal ending -on be identified with Slavic $-z$ and Lith. $-u$ as IE *-om? I think that the acc. sg. ending of the $o$-stems even offers independent evidence in support of this view.

16.

The phonetic reflex of IE *-um is -on in the Enchiridion, e.g. inf. daton (35.31), cf. Skt. dâtum. The acc. sg. ending of the $u$-stems occurs in the following instances: dangon $(13 \times)$, -an $(2 \times)$, Soünon $(2 \times)$, -an $(7 \times)$, adj. poligon (67.5). The form poligun (67.5), polligun (45.18) is a recent nominalization of the adverbial neuter form poligu. ${ }^{14}$ The ending -an was apparently borrowed from the $o$-stems, cf. gen. sg. Soünas $(4 \times)$. What was the basis for the introduction of the new case endings in the $u$-stems? I think that it was precisely the phonetic merger of the acc. sg. endings.

17.

The acc. sg. ending of the $o$-stems is -an. There is only one noun which has the ending -on, which is found in three out of four occurrences. This can hardly be accidental. The examples are the following:

(63.4) bhe etläikusin deickton prei kitawidintunsin "vnd enthalt sich etwas zuuerhindern",

(63.22) bhe pertraüki stan deickton sen mensan "vnd schlosz die stet ('Stätte') zu mit fleisch",

(71.36) en ainassei malnijkas deickton "an eines Kindes stat", 
(77.16) en stessei (adder en stessias) deicktan "an seiner (oder jrer) stat". The meaning 'etwas' is also attested in the fifth occurrence of this word in the Enchiridion, deicktas (65.6), which is in the genitive case. The ending -on is evidently archaic. It is also found in niainonton (37.34) 'niemand', muisieson (45.30) 'grösser', Pauson (75.35) 'wegen', enterpon (19.17) 'nützlich' next to pausan (71.36), enterpen (49.15). The ending of Swinton (31.27) must be corrected to -an, which is very frequent, and the form proston (73.8), which combines the only occurrence of the preposition pro with the only occurrence of the pronominal form ston, to prastan, which is found elsewhere $(17 \times)$. The form palasinsnon (55.23) must be corrected to polasinsnan, which occurs elsewhere $(2 \times)$.

18.

There are two categories where IE *-om is regularly reflected as -on in the Enchiridion. For higher numbers, cardinal and ordinal numerals have apparently merged:

(23.1) Stai Dessimton Pallaipsai "Die Zehen Gebot",

(27.25) Stas Dessimts Pallaips "Das Zehende Gebot",

(43.31) posteimans Dessimtons Pallaipsans "nach den Zehen Geboten",

(51.26) stans Dessimtons pallaipsans "die Zehen Gebot",

(55.23) Lucas en dessimton palasinsnon "Luce 10.",

(69.24) en Dessimton ast popeisauns "am 10. Cap. beschrieben hat",

(29.7) en tüsimtons streipstoos "in tausent Gelied".

The acc. pl. ending -ons is a secondary development of the indeclinable form in -on because there are no other examples of this ending. The form streipstoos must be corrected to streipstans, which occurs elsewhere (29.32). I regard the form in -on as the phonetic reflex of the neuter ordinal numeral.

19.

The acc. sg. ending of the passive participle is -on, e.g. ainangeminton (77.32), niwinüton (31.27), Ismaitinton (31.23), perklantiton (31.24), polaipinton (79.34), fem. pogauton (81.11), potaukinton (81.14). The only exception is found in stan pertrincktan Pharao (75.1). The neuter form of the passive participle, which is particularly frequent, always ends in -on, e.g. billìton $(20 \times)$, dāton (49.16), peisãton (67.4), podāton (51.1), pogalbton 
(71.34), poquoititon (69.16), Popeisāton (49.1), prolieiton (49.17). I think that the reason for the preservation of the archaic ending in this form must be sought in its specific syntactic use:

(43.21) stai grikai ast prastan etwierpton pirsdau Deiwan Endangon "die sünde seien dadurch vergeben für Gott im Himel",

(57.12) Quei adder aina aucktimmiskū ast, stai ast esse Deiwan Enteiküton "Wo aber Obrigkeyt ist, die ist vonn Gott geordnet",

(65.12) Stai gannai bousei pomeston swaain wijrin "Die Weiber sein vnterthan jren Mennern".

The neuter functioned apparently as an uninflected form and therefore resisted the analogical introduction of $-a n$ on the basis of the other case forms. On the contrary, it even occasioned the substitution of -on for original $-a n$ in the fem. acc. sg. form.

20.

After the examination of the Slavic and Baltic material, we now turn to the other branches of Indo-European. Latin and Oscan do not reveal anything. As Meillet pointed out already (1922: 259), the Umbrian gen. pl. forms testify unambiguously to IE *-om, e.g. fratrom (VIIb 1). The only exception is pracatarum (VIa 13), where -arum replaces earlier *-um from *-aHom.

\section{1.}

The Old Irish gen. pl. form fer can only represent IE *-om (cf. Meillet 1922: 258). Thurneysen's suggestion (1975: 60) that the ending continues IE *-om which was shortened at an early stage is neither supported by comparable sound changes nor corroborated by other instances than this very ending. It requires the following relative chronology:

(1) Long vowels were shortened before final nasals.

(2) ${ }^{*} \bar{o}$ became $\bar{u}$ in final syllables, $\bar{a}$ elsewhere. ${ }^{15}$

(3) $i$ - and $u$-diphthongs in final syllables were monophthongized. ${ }^{16}$

(4) ${ }^{*} \bar{e}$ became $i{ }^{17}$

(5) Long final vowels were shortened.

(6) $i$ and $u$ were lowered to $e$ and $o$ when the following syllable contained a non-high vowel except final $e .^{18}$ 
(7) Final dentals were lost. ${ }^{19}$

(8) Short final vowels were lost except after $i{ }^{20}$

(9) Long vowels in final syllables were shortened.

No development can be demonstrated to have been anterior to (1). Moreover, the supposition that IE $*_{-}-\bar{o} m$ yields the same reflex as $*_{\text {-om }}$ forces Thurneysen to assume $(1975: 362)$ that the absolute form of the 1 st sg. subj. bera is analogical and that the conjunct form .ber is phonetically regular. This cannot be correct because there is no model for the ending - $a$ whereas the form .ber is easily explained as an analogical formation on the basis of the s-subjunctive, e.g. tiasu, tias. I think that the conjunct forms .biur, .bir, .beir reflect the original thematic endings (Meillet 1907: 371) and that the absolute forms biru, biri, berith represent *bhero- $m$, ${ }^{*}$ bherei-s, *bhere-t-is (cf. Meillet 1908: 414). ${ }^{21}$

22.

The origin of the Gothic gen. pl. ending $-\bar{e}$ is one of the most debated problems in Germanic historical morphology. ${ }^{22}$ Yet I think that the solution is not only simple, but implicitly given in the more or less generally acknowledged truths about Germanic historical phonology. The distribution of masc. $-\bar{e}$ and fem. $-\bar{o}$ is undoubtedly recent and warrants the assumption that the ending $-\bar{e}$ originated from one of those flexion classes where it characterizes both masc. and fem. nouns. Indeed, it can hardly be analogical in the $i$-stems because there is no formative element before the ending in gastê, mahtē. Germanic inherited from the Indo-European protolanguage two types of $i$-flexion, a proterodynamic paradigm with accentual mobility between the root and the formative suffix, e.g. Skt. ásthi, and a hysterodynamic paradigm with accentual mobility between the formative suffix and the ending, e.g. Skt. sákhā (cf. Kuiper 1942). If the IE gen. pl. ending was *om, the proterodynamic and hysterodynamic forms ended

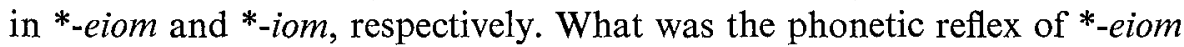
in Germanic? This problem must be viewed in connection with the rise of the so-called $\bar{e}_{2}$. Van Coetsem has convincingly argued (1956: 22ff) that $\bar{e}_{2}$ is the phonetic reflex of *ei when the following syllable contained a low vowel. Thus, the expected gen. pl. ending of the proterodynamic $i$-stems is $-\bar{e}$ in Gothic. ${ }^{23}$ I conclude that gaste is phonetically regular. ${ }^{24}$ The hysterodynamic gen. pl. ending was preserved in prije (with secondary $-\bar{e}$ ), cf. Lith. trijü Gr. $\tau p \iota \hat{\omega} \nu$. 
23.

Why is the gen. pl. ending $-\bar{e}$ not attested in the other Germanic languages? I think that the proterodynamic paradigm was preserved in Gothic while the other languages largely generalized the hysterodynamic flexion type. This point of view is supported by the correspondence of Gothic barytona with oxytona in other languages (cf. Barber 1932: 18ff):

Go. gafähs, ON. fengr, OE. feng, OHG. fang.

Go. slahs, ON. slagr, OE. slege, OHG. slag.

Go. plauhs, ON. flugr.

Go. drus, OE. dryre.

Go. wrōhs, ON. rōg.

Go. gabaurps, OE. gebyrd, OHG. giburt.

Go. gaqumps, ON. samkund, OHG. cumft.

Go. naups, OE. nied, OHG. nōt.

Go. asans, ON. gnn.

There is one counter-example: OE. earfop vs. Go. arbaips, OHG. arabeit.

24.

It is generally assumed that the masc. $n$-stems took their plural case endings from the $o$-stems in Old Norse. But what was the starting-point of this analogical development? The embarrassing fact is that the two flexion classes have no singular case form in common. If we assume that the original gen. pl. ending was ${ }^{*}$-om, the corresponding form hana is phonetically regular and provides the basis for the analogical introduction of the new endings in the other case forms of the plural.

25.

The prevalent reading of the text on the Pietroasa gold ring is GUTANIOWIHAILAG. ${ }^{25}$ The most attractive interpretation is undoubtedly Marstrander's (1929: 51): Gutani owi hailag "Gutonum possessio sacra" or "Gutonum tutamentum sacrum". The objection which Marstrander raised himself and which has remained the only one in the literature on the subject, viz. that the monophthongization of *au to $o$ in $o w i$ impels one to expect ${ }^{* *} e$ instead of $a i$ in hailag, does not hold because it is not only con- 
ceivable, but even probable that the monophthongization was later in the latter word. There is a chronological difficulty however. Since the narrowing of $-\bar{e}$ to $-\bar{i}$ cannot be dated earlier than the fifth century, Marstrander's reading is incompatible with the usual dating of the inscription. If both the early dating of the text and the interpretation of the first word as a gen. pl. form are upheld, we must assume that the ending was zero, which can be identified with IE *-om (cf. Vendryes 1927: 367). I prefer to retain Marstrander's reading and, consequently, to date the text to the 5th century. ${ }^{26}$ The ring itself may date from the 3rd century.

26.

The Gothic gen. pl. ending $-\bar{o}$ cannot be the phonetic reflex of IE ${ }^{*}-\bar{m} m$ because the latter would undoubtedly have coincided with ${ }^{*_{-} o n}$ and ${ }^{*}-\bar{a} m$. This ending is attested in the nom. sg. of the $n$-stems, e.g. Go. hana, OE. tunge, OHG. zunga, and in the acc. sg. of the $\bar{a}$-stems, e.g. Go. giba, ON. gief, OE. giefe, OHG. geba. ${ }^{27}$ I find no evidence for tonal distinctions in Germanic. ${ }^{28}$ The distribution of $-\bar{e}$ and $-\bar{o}$ in Gothic shows that the origin of the latter ending must be sought in the $\vec{a}$-stems. According to the Slavic, Baltic, and Celtic evidence, the IE ending *-om was added immediately to the root or to a stem alternant with zero grade before the laryngeal. ${ }^{29}$ This cannot be due to a secondary development because the elimination of the characteristic formative vowel before the gen. pl. ending would be an unmotivated innovation. The converse development, the analogical introduction of the formative vowel before the case ending, is quite natural and must also be assumed for Greek and Indo-Iranian. Since the attested gen. pl. ending differs from the expected reflex of IE $*_{-o} m$, the analogic change cannot have been anterior to the loss of the laryngeals in Germanic. On the other hand, it was certainly anterior to the loss of final syllables. Thus, I reconstruct a Common Germanic ending *-oan, which subsequently developed into the attested forms in accordance with the sound laws of the different languages. The new ending spread to the fem. $n$-stems in Gothic and was generalized elsewhere.

\section{7.}

The Avestan form staräm (Y 44.3) differs from other gen. pl. forms in two respects: the ending is monosyllabic and shows $a$ instead of $q$ (cf. 
Insler 1975: 243). This is the expected reflex of IE *-om. Bartholomae's interpretation of kahrpām (Y 30.7), sarām (Y 49.9), dāazm (Y 50.2) as gen. pl. forms was rejected by later investigators precisely because of their monosyllabic ending (cf. Humbach 1959: 31). The gen. pl. form kahrpam (YH 36.6) is not Gãthic. The only instance of a monosyllabic gen. pl. ending -ąm in Gāthic outside Y 53 is found in amavatąm (Y 43.10), which is used predicatively (cf. Insler 1975: 63). Since the reflex of IE *-om is beyond doubt in staram, there may be reason to reconsider the other forms against this background.

28.

What is the origin of IE *-om? The Sanskrit gen. pl. forms asmákam, yușmákam and their Iranian cognates are formally identical to the neuter form of a possessive adjective. The same holds for Latin nostrum, vestrum and Old Norse vār, ypvar. ${ }^{30}$ The identity of Gothic unsara, izwara with the plural form of the neuter possessive adjective is generally recognized. The morphological identity of gen. pl. and poss. adj. forms is complemented by their syntactic equivalence. ${ }^{31}$ Thus, the origin of the gen. pl. in *-om must probably be sought in such instances as RV 4.22.10 asmăkkam it sú śrnuhi tvám indra, where 'listen to us' may be derived from 'listen to ours',

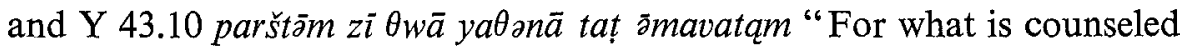
through thy effort, that belongs to the forceful" (Insler 1975: 63), which is the only place outside Y 53 where a monosyllabic gen. pl. ending -am is found in Gäthic, cf. also Old Persian hyā amäxam tauma ' the family which is ours'. I think that the gen. pl. in *-om developed from an uninflected predicative form in late Indo-European. The development of inflected forms which turned the original predicative into a possessive adjective belongs to the separate languages. This process is taking place before our eyes in the Old Prussian Enchiridion.

29.

If the hypothesis advanced here is correct, the oldest type of syntactic construction is exemplified in Slavic tacěxz bo jestz cěsarbstvije božije,

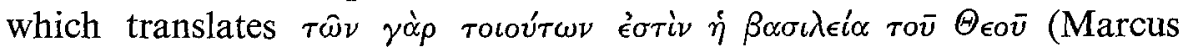

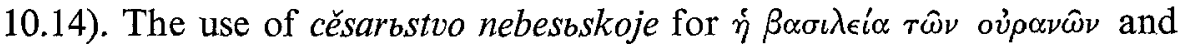




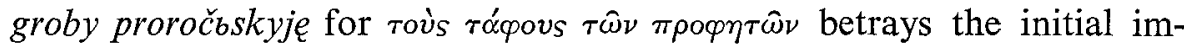
possibility to render the Greek original without changing its formal structure (cf. Vaillant 1935: 9). The gen. pl. form had apparently not yet attained the full range of its attributive usage. The formative suffix of the adjective in syn božij etc. may be identical with the gen. sg. ending $-i$ in Italic and Celtic, which correlates with the plural ending *-om, e.g. Latin mei, tui next to nostrum, vestrum.

30.

A parallel to the development suggested here for Indo-European is found in Armenian. In this language, the suffix *-sko-, which is attested in the derived adjectives that replace the gen. pl. forms in the above Slavic examples, yielded a new gen. pl. form, e.g. $k^{c} n o c$, which is the phonetic reflex of IE *suopnoskom (cf. Meillet 1936: 72). If the hypothesis that this form developed from an uninflected predicative can be maintained here as well, the original syntax has been preserved in aranc linein, lit. 'of-men they-became', which translates '́ $\gamma \alpha \mu i \zeta o v \tau o$ (Lucas 17.27).

31.

What was the meaning of the original predicative in *om? The absence

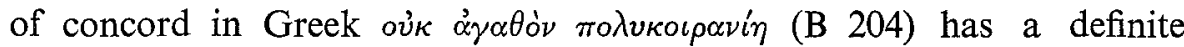
semantic correlate: the adjective may be paraphrased as "pertaining to the category of portions of reality which carry the feature "good"". The same meaning can be established for the Hittite so-called gen. pl. ending -an, which is formally identical to the neuter sg. ending -an and can be identified with IE *-om. As Laroche puts it (1965: 40), "la question de savoir si la désinence -an est du singulier ou du pluriel s'évanouit. Problème mal posé: le génitif en -an est de collectif, comme il apparaît clairement à la liste des noms qui le possèdent, êtres ou catégories allant par groupes". ${ }^{32}$ This is also the origin of the pronominal gen. sg. ending -on in Old Prussian stëison, tennēison, for which no acceptable solution has been put forward by earlier investigators. ${ }^{33}$

32.

The Greek gen. pl. forms require the following relative chronology:

(1) Substitution of $*_{-a H o m}$ for $*_{-o m}$ in the $a H$-stems. 
(2) Substitution of *oom for *om in the $o$-stems.

(3) Contraction of the dissyllabic gen. pl. endings to *o-m.

(4) Introduction of ${ }^{*}-\bar{o} m$ in the consonant stems.

(5) Introduction of the new ending in the pronoun.

(6) Substitution of the pronominal ending *-āsōn for *-ōn in the $\bar{a}$-stems. The first of these stages may have been a common development of IndoIranian, Greek, and Italic, and represent an IE dialectal innovation. In Indo-Iranian, the ending -aam was generalized after the merger of ${ }^{*} e$ and $* o$.

33.

Methodologically, the history of the gen. pl. is interesting because it demonstrates how a single false assumption, viz. the identification of Gr. $-\omega \nu$ and Skt. $-\bar{a} m$ as IE *-om, led to a misinterpretation of the relation between quantitative differences in Slavic, between - $u$ and $-q$ in Lithuanian, between -on and - $a n$ in Old Prussian, between absolute and conjunct subj. endings in Old Irish, between $-\bar{e}$ and $-\bar{o}$ in Gothic, between masc. en fem. $n$-stems in Germanic, between monosyllabic - $\bar{m} m$ and dissyllabic -am in Avestan. It shows that the reconstruction of the proto-language must be based on a previous detached analysis of the internal chronological evidence which the daughter languages supply.

\section{Notes}

${ }^{1}$ For a fuller account of these developments and their chronological implications I refer to Kortlandt 1975: 29-34.

${ }^{2}$ For the same reason, the analogical spread of length in the neuter nom. pl. ending $-a$ did not reach SIn. drvà, cf. Kortlandt 1975: 32.

${ }^{3}$ Cf. Dunaj 1966: 37f; Trávníček 1935: 263f; Lorentz 1903: 262. I use a simplified variant of Lorentz's orthography.

${ }^{4}$ As a rule, the short vowel was generalized before final voiceless consonants in Slovincian. The original state of affairs is still attested in pùotros, gen.pl. potróus. The motivation for the Slovincian development must be sought in the merger of the Proto-Slavic accentual mobilia with the class of nouns with fixed stress on a non-initial syllable in this language.

${ }^{5}$ The short vowel in such instances as záhrad (gen.pl. of záhrada) reflects the neutralization of length after a long vowel in the preceding syllable.

${ }^{6}$ This is a correction to Kortlandt 1975: xii. In Ukrainian, short vowels were lengthened in monosyllables, e.g. kin', SIn. kònj. The $\hat{o}$ of Russ.dial. kônj, morôz reflects Proto-Slavic rising pitch, not length.

${ }^{7}$ Cf. Bulaxovskij 1958: 87f. Sometimes both forms are attested, e.g, bolót, bolit. 
${ }^{8}$ The material is difficult to evaluate. Sln. ovâc, dosâk must be younger than Cak. ovác, dasák because these words were accentually mobile in Proto-Slavic. Though most nouns with the suffix $-b c$ - had fixed stress on the suffix before Dybo's law operated (cf. Dybo 1968: $175 f f)$, both the Old Russian and the South Slavic material point to accentual mobility of the word ovca (cf. Dolobko 1926: 131), which is in accordance with Sanskrit aviká. Though the gen.pl. form óvac (Ramovš 1921: 234) cannot therefore be phonetically regular, its existence requires a model of the type which is found in Cakavian. The model may actually be attested in the gen.pl. lónac, cf. SCr. lönācā.

${ }^{9}$ For the history of the problem cf. especially Karlgren 1911; Ružičić 1927: Svane 1958.

${ }^{10}$ Oblak's point of view is supported by the fact that we find e.g. gen. pl. vodé next to dat. p1. vodém in the Venetian dialect of Slovene. Cf. also Ramovš 1923: 211 .

${ }^{11}$ Rešetar's argument (1898: 137) that in the East Montenegrin dialects which keep the reflex of the jers distinct from $a$ the former is found in the gen. pl. ending does not refute this point of view because in these dialects the gen. pl. and loc. pl. have merged and because the reflex of the jers often corresponds to etymological $a$. I find slight indications that the latter correspondence is phonetically regular in closed syllables, though the original distribution has largely been obliterated, cf. the l-participle prödäa, özvä (Miletić 1940: 236). According to Stevanovic (1933: 67), the vowel timbre of the gen. pl. ending must be derived from the original loc. pl. endings of the $i$ - and $u$-stems, which contained a jer. If this suggestion is correct, we have to assume for these dialects a development which is similar (but not identical) to the one proposed by Johnson. Liukkonen's recent endeavour (1974) is not convincing.

${ }^{12} \mathrm{I}$ am glad to see that this point of view, which is diametrically opposed to Schmalstieg's (1974), is now shared by Levin (1976). It was also supported by Saussure (1892) and Meillet (1919), but the work of these authors is apparently unknown to Schmalstieg.

${ }^{13}$ The indication of occurrences refers to Trautmann 1910.

${ }^{14}$ For the meaning cf. Deiws teikü stan smunentin sebbei supsmu en prusnanpoligon, ia prei prusnas poligun Deiwas teiku tāns tennan "Gott Schuff den Menschen, Im selbst zum Bilde [Trautmann: 'im Angesichte gleich'], Ja zum Bilde [Trautmann: 'zum Gleichen, zur Gleichheit des Angesichts'] Gottes schuff er jn".

${ }^{15}$ (1) ANTE (2) because fer points to a lost neutral vowel.

${ }^{16}$ (2) ANTE (3) because the result of the monophthongization was probably ${ }^{*} \bar{e}$ and ${ }^{*} \bar{\delta}$, and the latter did not merge with earlier $* \bar{o}$. The development is similar to what we find in Slavic, where the $u$-diphthongs were monophthongized to ${ }^{*} \bar{o}$ (later $u$ ) at a stage when the original ${ }^{*} \bar{o}$ had become ${ }^{*} \bar{u}$ (later $y$ ) before nasals in final syllables and ${ }^{*} \bar{a}$ (later $a$ ) elsewhere, e.g. kamy, dati.

17 (3) ANTE (4) because original final $i$-diphthongs have the same effect as $i$, e.g. nom. pl. $f i r$. In Slavic, too, ${ }^{*} o i$ and $*_{a i}$ merged with ${ }^{*} \bar{e}$, e.g. nom. du. recě.

${ }^{18}$ This formulation of the rule accounts for the difference between voc. sg. fir and nom. pl. coin, 3rd sg. pres. fo.loing (cf. Thurneysen 1975: 47). I think that (6) was posterior to (5) because distinctively short $e$ before a final consonant was apparently lower than word-final $e$, which was phonemically neutral with respect to quantity after the shortening of long final vowels.

${ }^{19}$ (6) ANTE (7) because of 3rd sg. pres. .beir, etc. (Lewis and Pedersen 1937: 65).

${ }^{20}$ (7) ANTE (8) because the latter rule applies both to original final vowels and to short vowels before original final consonants that were lost.

${ }^{21} 3$ rd pl. berait from *bhero-nt-ei.

${ }^{22}$ Cf. Makaev 1963: 164-168; Morgenroth 1965; Lehmann 1967; Bech 1969. None of these authors mentions more than half of the earlier explanations.

${ }^{23}$ The possibility of deriving Gothic $-\bar{e}$ from *-eiom was first suggested orally by Meillet (cf. Vendryes 1927: $368 \mathrm{fn}$.). This hypothesis and Van Coetsem's $a$-umlaut now corroborate 
each other. Brugmann's conjecture (1914: 279) that $-\bar{e}$ represents *-eitom is not only morphologically unfounded but also phonetically impossible, cf. saian, waian. The relation between $a i$ in these verbs and $\bar{e}_{1}$ elsewhere is reminiscent of the relation between $\bar{e}_{2}$ in the gen, pl. ending and $e i$ elsewhere.

${ }^{24}$ The proterodynamic paradigm of this word is supported by the short root vowel in Cak. göst (Jurišić 1973: 62) and Kajk. gèst (Rožić 1893: 100).

${ }^{25}$ Cf. Arntz and Zeiss 1939: 52ff and Høst 1971: 48ff.

${ }^{26}$ Arntz's dating (1939: 66) is no more than a conjecture.

${ }^{27}$ It is generally assumed that the nom. sg. ending was substituted for the acc. sg. ending in ON. giof. I am unable to share this view because I fail to see the motivation for the analogic change. The nom. sg. and acc. sg. forms are distinct in the other flexion classes of this language. The acc. sg. form of the adjective spaka has a pronominal ending. This is an innovation of Old Norse, just as the introduction of the pronominal ending in the neuter form spakt. It has long been recognized that the final vowel of Go. tuggo was taken from the other case forms. The same must be assumed for ON. tunga, OE. hona, OHG. hano. The ending of ON. hani was taken from the ion-stems (cf. Lid 1952). There is no evidence for IE *-en outside Greek. In the $r$-stems, IE *-or was preserved in Runic swestar (Andersen 1960: 409f), then replaced by the reflex of IE *-err in ON. systir on the basis of the other kinship terms, cf. Lith. sesuó vs. móté, Skt. acc. sg. svásäram vs. mätáram.

${ }^{28}$ The opposition between Go. galeiko and baira, ON. glika and ber, OHG. gilicho and biru is accounted for by the presence vs. absence of a final dental stop.

${ }^{29}$ The same formation is attested in such adjectives as Slavic triglavb (Vaillant 1958: 84).

${ }^{30} \mathrm{Cf}$. Vaillant (1935: 8): "interpréter uterque nostrum 'chacun de nous' par 'chacun des nôtres' ressemble fort à de l'étymologie populaire, et il faut plutôt penser que nostrum, uostrum sont en latin des formes traditionnelles dont le lien avec les possessifs avait cessé d'être compris". ON. vār cannot be identified with Go. unsara because of the absence of $u$-umlaut.

${ }^{31}$ Cf. Meillet (1934: 346): "la construction du génitif est donc parallèle de tous points à celle de l'adjectif".

${ }^{32}$ Pedersen already translated 'Gottesstädte' (reading URU for UTU), 'Königstor', 'Königshaus' (1938: 32).

${ }^{33}$ Cf. Trautmann 1910: 263f. Stang calls the ending simply 'fehlerhaft' (1966: 243), which is unsatisfactory because of its remarkable frequency.

\section{References}

Andersen, H., 1960. Opedalstenen. Norsk Tidsskrift for Sprogvidenskap 19, 393-417.

Arntz, H., and H. Zeiss, 1939. Die einheimischen Runendenkmäler des Festlandes. Leipzig. Barber, C.C., 1932. Die vorgeschichtliche Betonung der germanischen Substantiva und Adjektiva. Heidelberg.

Bech, G., 1969. Über die gotischen Gen.Pl.-Endungen. Lingua 23, 55-65.

Belić, A., 1909. Zamětki po čakavskim govoram. Izvěstija Otdělenija russkago jazyka i slovesnosti 14(2), 181-266.

Brugmann, K., 1914. Der gotische Genitivus Pluralis auf $-\bar{e}$. Indogermanische Forschungen $33,272-284$.

Bulaxovskij, L.A., 1958. Otraženija tak nazyvaemoj novoakutovoj intonacii drevnejšego slavjanskogo jazyka v vostočnoslavjanskix. Voprosy jazykoznanija 7 (2), 87-92.

Van Coetsem, F., 1956. Das System der starken Verba und die Periodisierung im älteren Germanischen. Amsterdam. 
Dolobko, M., 1926. Der sekundäre $v$-Vorschlag im Russischen. Zeitschrift für slavische Philologie 3, 87-144.

Dunaj, B., 1966. Wzdłużenie zastępcze w języku polskim. Kraków.

Dybo, V.A., 1968. Akcentologija i slovoobrazovanie v slavjanskom. Slavjanskoe jazykoznanie 6, 148-224.

Høst, G., 1971. Spuren der Groten im Osten. Norsk Tidsskrift for Sprogvidenskap 25, 45-90.

Humbach, H., 1959. Die Gathas des Zarathustra I. Heidelberg.

Insler, S., 1975. The Gāthās of Zarathustra. Leiden.

Johnson, D.J.L., 1972. The genesis of the Serbo-Croatian genitive plural in $-\bar{a}$. The Slavonic and East European Review 50(120), 333-358.

Jurišić, B., 1973. Rječnik govora otoka Vrgade II. Zagreb.

Karlgren, A., 1911. Sur la formation du gén. plur. en serbe. Uppsala.

Kodov, H., 1929. Podvižnoto bəlgarsko udarenie i negovoto otnošenie kəm praslavjanskoto udarenie I: Səštestvitelni imena. Sofija.

Kortlandt, F.H.H., 1975. Slavic accentuation: A study in relative chronology. Lisse.

Kortlandt, F.H.H., 1977. Historical laws of Baltic accentuation. Baltistica 13, 103-114.

Kuiper, F.B.J., 1942. Notes on Vedic noun-inflexion. Amsterdam.

Laroche, E., 1965. Études de linguistique anatolienne. Revue hittite et asianique 23(76), 33-54.

Lehmann, W.P., 1967. The Gothic genitive plural $-\bar{e}$ : Focus of exercises in theory. Papers in linguistics in honor of Léon Dostert, 108-111. The Hague.

Levin, J.F., 1976. Toward a graphology of Old Prussian monuments: The Enchiridion. Baltistica 12, 9-24.

Lewis, H., and H. Pedersen, 1937. A concise comparative Celtic grammar. Göttingen.

Lid, N., 1952. Den nordiske nominativ singularis av maskuline an-stammer. Norsk Tidsskrift for Sprogvidenskap 16, 237-240.

Liukkonen, K., 1974. Der Ursprung des štokavischen Gen. Pl. auf $-\bar{a}$, Scando-Slavica 20, 159-164.

Lorentz, F., 1903. Slovinzische Grammatik. St. Petersburg.

Makaev, Ė.A., 1963. Imennoe sklonenie v germanskix jazykax. Sravnitel'naja grammatika germanskix jazykov III, Moskva. 132-302.

Marstrander, C.J.S., 1929. De gotiske runeminnesmerker. Norsk Tidsskrift for Sprogvidenskap 3, 25-157.

Meillet, A., 1907. Sur l'origine de la distinction des flexions conjointe et absolue dans le verbe irlandais. Revue celtique 28, 369-373.

Meillet, A., 1908. A propos de v. irl. beri. Mémoires de la Société de Linguistique 14, 412415.

Meillet, A., 1919. Dissimilation vocalique en vieux prussien. Bulletin de la Société de Linguistique $21,131-132$.

Meillet, A., 1922. La forme du génitif pluriel en ombrien. Mémoires de la Société de Linguistique 22, 258-259.

Meillet, A., 1934. Introduction à l'étude comparative des langues indo-européennes. Paris.

Meillet, A., 1936. Esquisse d'une grammaire comparée de l'arménien classique. Vienne.

Miletić, B., 1940. Crmnički govor. Srpski dijalektološki zbornik 9, 209-663.

Morgenroth, W., 1965. Der Genitiv Pluralis im Gotischen. Beiträge zur Geschichte der deutschen Sprache und Literatur (Halle) 87, 328-336.

Moskovljević, M., 1950. Govor ostrva Korčule. Srpski dijalektološki zbornik 11, 153-223.

Oblak, V., 1890. Zur Geschichte der nominalen Declination im Slovenischen. Archiv für slavische Philologie 12, 1-47, 358-450.

Pedersen, H., 1938. Hittitisch und die anderen indoeuropäischen Sprachen. København.

Ramovš, F., 1921. O slovenskem novoakutiranem $o$. Južnoslovenski Filolog 2, 227-239. 
Ramovš, F., 1923. K poznâvanju praslovanske metatonije. Slavia 2, 205-231.

Rešetar, M., 1898. Primorski lekcionari XV vijeka. Rad 136, 97-199.

Rožić, V., 1893. Kajkavački dijalekat u Prigorju. Rad 115, 68-136.

Ružičić, G., 1927. Razvitak srpskohrvatskog gen. pl. na -ă. Slavia 5, 214-232.

Saussure, F. de, 1892. Traitement de l'â en vieux prussien. Mémoires de la Société de Linguistique 7, 80-82.

Schmalstieg, W.R., 1974. An Old Prussian grammar. University Park.

Stang, C.S., 1957. Slavonic accentuation. Oslo.

Stang, C.S., 1966. Vergleichende Grammatik der baltischen Sprachen. Oslo.

Steinhauer, H., 1973. Cakavian studies. The Hague.

Stevanović, M.S., 1933. Istočnocrnogorski dijalekat. Južnoslovenski Filolog 13, 1-128.

Svane, G.O., 1958. Die Flexionen in štokavischen Texten aus dem Zeitraum 1350-1400. Aarhus.

Thurneysen, R., 1975. A grammar of Old Irish. Dublin.

Trautmann, R., 1910. Die altpreussischen Sprachdenkmäler. Göttingen.

Trávniček, F., 1935. Historická mluvnice ceskoslovenská. Praha.

Vaillant, A., 1935. Le génitif pluriel en *-on. Revue des Études Slaves 15, 5-11.

Vaillant, A., 1958. Grammaire comparée des langues slaves II. Lyon.

Vendryes, J., 1927. Sur le génitif pluriel des substantifs en germanique. Indogermanische Forschungen 45, 364-369.

Van Wijk, N., 1923. Die baltischen und slavischen Akzent- und Intonationssysteme. Amsterdam.

Winter, W., 1976. The distribution of short and long vowels in stems of the type Lith. ësti : vèsti : mèsti and OCS. jasti : vesti : mesti in Baltic and Slavic languages. Recent developments in historical phonology, 431-446. The Hague. 